\title{
COVID-19 Hastalarında Lopinavir/Ritonavir ve Favipravir Deneyimi
}

\section{Lopinavir/Ritonavir and Favipravir Experience in COVID-19 Patients

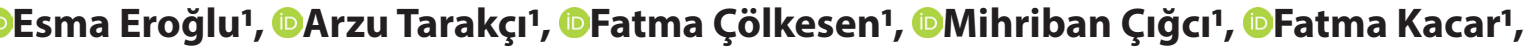 \\ ๑Şule Özdemir Armağan'1
}

'Sağlık Bilimleri Üniversitesi, Konya Eğitim ve Araştırma Hastanesi, Konya, Turkey

\section{Öz}

Giriş: COVID-19 şu anda küresel sağlık için büyük bir tehdittir. Bununla birlikte, tedavisi için spesifik bir antiviral ajan mevcut değildir. Bu çalısmada; Favipiravir (FPV) ve Lopinavir/Ritonavir (LPV / RTV) ile tedavi edilen hastalarda tedavinin klinik etkinliğinin ve ilaç yan etkilerinin değerlendirmesi amaçlandı.

Gereç ve Yöntem: Çalışmaya üçüncü basamak bir hastanede enfeksiyon hastalıkları servisinde 15.03.2020-30.04.2020 tarihleri arasında COVID-19 tanısı ile yatırılarak takip edilen FPV ve LPV / RTV tedavisi alan 46 hasta dahil edildi. Tüm hastaların COVID-19 tanısı real time polimeraz zincir reaksiyonu (RT-PCR) ile konfirme edildi.

Bulgular: COVID-19 tanısı alan 46 olgu çalışmaya alınmıştır. Hastaların 29'u (\%63) erkek, 17'si (\%37) kadındı. Toplam 46 hasta iki grupta değerlendirildi. Birinci grupta FPV kullanan 34 hasta, ikinci grupta LPV/RTV kullanan 12 hasta mevcuttu. Yaş ortalaması 57.8 \pm 17.7 (yaş aralığı 18-91). Birinci grubun yaş ortalaması $57,71 \pm 17,33$, ikinci grubun yaş ortalaması $58 . \pm 18.8$ idi. Hastaların tümünde ateş en sık başvuru semptomu idi $(\% 69,6)$. FPV kolunda sırasıyla ateş (\%68.8), halsizlik (\%77.8), öksürük \%69.2 en sık başvuru semptomları idi. LPV/RTV kolunda sırasıyla ateş (\%31.2), öksürük (\%30.8), boğaz ağrısı (\%28.6)en sık başvuru semptomları idi. FPV kolunda ateşi olan hastaların tedavi ile ortalama normale dönüş süresi $3.56 \pm 1$ gün iken LPV/ RTV kolunda ateşin normale dönme süresi $4,42 \pm 1$ gün idi. FPV kolunda daha hızlı olan ateşin normale dönme süresi istatistiksel olarak anlamlı bulundu (p: 0.03). Karaciğer enzim yüksekliği FPV kolunda belirgin yüksekti (\%20.6). Bulantı-kusma ise LPV/RTV kolunda yüksek (sırasıyla \%41.7, \%25) görüldü. Bu yükseklik istatistiksel olarak anlamlı idi ( $p$ değeri sırasıyla 0.009 ve 0.04). illaç kesilmesini gerektiren ciddi bir yan etki gelişmedi.

Sonuç: SARS-CoV-2 enfeksiyonu için henüz bilinen, etkinliği güvenilir çalışma sonuçları ile gösterilmiş bir tedavi bulunmamaktadır belirli ilaçlar henüz șimdilik birleștirilmemiștir. Hedefimiz, eldeki verilerle etkili tedavileri tanımlamak için sonuçları paylaşmaktı. LPV/RTV tedavisi ile viral kilerens oldukça yüksek iken yan etki neredeyse tüm hastalarda görülmüştür. FVP kullanan hastalarda viral kilerens LPV/RTV koluna göre daha az olmakla beraber ilaca bağlı gelişen yan etkilerde daha azdı. Sonuçlarımız SARSCoV-2 enfeksiyonunun tedavisi için ön veri sağlamıștır. Ayrıca, antiviral tedavi denemeleri için birincil son nokta olarak kullanılabilen ve COVID-19 ile ilgili tedavileri araştıran protokollerin tasarlanması için faydalı bir sonuç olabilecek viral klirens zamanını ve yan etki spektrumunu göstermeye çalıştık COVID-19 tedavisinde etkinliği tam olarak bilinmeyen bu ilaçların yarar sağlayacağı umut edilmektedir,

Anahtar Kelimeler: COVID-19, Favipravir, Lopinavir/Ritonavir

\begin{abstract}
Introduction: COVID-19 is currently a major threat to global health. However there is no specific antiviral agent available for its treatment. In this study; It was aimed to evaluate the clinical efficacy of treatment and drug side effects in patients treated with Favipiravir (FPV) and Lopinavir / Ritonavir (LPV / RTV).

Material and Method: 46 patients who were hospitalized with the diagnosis of COVID-19 and received FPV and LPV / RTV treatment between 15.03.202030.04.2020 in an infectious diseases service in a tertiary hospital were included in the study. The diagnosis of COVID-19 in all patients was confirmed by real time polymerase chain reaction (RT-PCR)

Results: Forty-six cases diagnosed with COVID-19 were included in the study. Twenty-nine $(63 \%)$ of the patients were male and seventeen (37\%) were female .A total of 46 patients were evaluated in two groups. There were 34 patients using FPV in the first group and 12 patients using LPV / RTV in the second group. Average age 57.8 \pm 17.7 (age range 18-91). The mean age of the first group was $57.71 \pm 17.33$, the second group was $58 . \pm 18.8$. Fever was the most common symptom in all patients (69.6\%). In the FPV arm, fever $(68.8 \%)$, weakness $(77.8 \%)$, cough were the most common symptoms at $69.2 \%$, respectively. Fever (31.2\%), cough (30.8\%) and sore throat (28.6\%) were the most common presenting symptoms in the LPV / RTV arm, respectively. Patients with fever in the FPV arm had a mean recovery time of $3.56 \pm 1$ days with treatment, and $4.42 \pm 1$ days in the LPV / RTV arm. The time to return to normal fever in the FPV arm was statistically significant (p: 0.03). Liver enzyme elevation was significantly higher in the FPV arm (20.6\%). Nausea and vomiting were observed to be high in the LPV / RTV arm ( $41.7 \%, 25 \%$, respectively). This height was statistically significant ( $p$ value 0.009 and 0.04 , respectively). There were no serious side effects that required drug withdrawal.

Conclusion: There is no known treatment for SARS-CoV-2 infection yet, with proven efficacy with reliable study results, certain drugs have not yet been combined. Our goal was to share the results with the available data to identify effective treatments. While viral clearance is quite high with LPV / RTV treatment, side effects were observed in almost all patients. Although viral clearance was less in patients using FVP compared to the LPV / RTV arm, side effects due to the drug were less. Our results provided preliminary data for the treatment of SARS-CoV-2 infection. In addition, we tried to show the viral clearance time and the spectrum of side effects, which can be used as the primary endpoint for antiviral treatment trials and can be a useful outcome for designing protocols investigating COVID-19-related treatments.
\end{abstract}

Keywords: COVID-19, Favipravir, Lopinavir/Ritonavir

Corresponding (illetişim): Esma Eroğlu, Sağlık Bilimleri Üniversitesi, Konya Eğitim ve Araştırma Hastanesi, Enfeksiyon Hastalıkları ve Klinik Mikrobiyoloji, Konya, Türkiye

E-mail (E-posta): esmagulesen@hotmail.com

Received (Geliş Tarihi): 22.06.2020 Accepted (Kabul Tarihi): 28.09.2020 


\section{GíRiş}

Yeni ciddi akut solunum sendromu koronavirüs 2'nin (SARSCoV-2) neden olduğukoronavirüs hastalığı 2019 (COVID-19) salgını, önleme ve tedavi için etkili ilaçların kullanılması oldukça zorluklar içermektedir. SARS-CoV-2 tarafından hızla enfekte olan çok sayıda hastanın klinik verileri hızı bir şekilde göz önüne alındığında, klinisyenler bu enfeksiyon için etkili tıbbi tedavilerle ilgili doğru kanıtlara intiyaç duymaktadır. COVID-19'a karşı mücadelede koronavirüsün önemli derecede bulaştırıcı olması ve hastalıktan korunmada en önemli basamak olan aşının henüz olmaması nedeniyle diğer önlemlerin hızlı ve en etkili şekilde uygulanması ön plana çıkmaktadır. Şu ana kadar bu virüsün henüz bilinen, etkinliği güvenilir çalışma sonuçları ile gösterilmiş bir tedavisi bulunmamaktadır. Çalışmamızda da adı geçecek tedaviler bugün için; acil durumda devreye girmiş, COVID-19 tedavisinde etkinliği tam olarak bilinmeyen, başka alanlardaki kullanımları veya in vitro çalışma sonuçları nedeniyle yarar sağlayacağı umut edilen ilaçlardır. ${ }^{[1]}$

Favipiravir: Bir nükleotid analoğudur. Japonya'da influenza tedavisi için onay almış bir antiviral ajandır. Özellikle İnfluenza ve Ebola'nın tedavisinde etkin olarak kullanılmıştır. Bunların yanı sırapek çok RNA virusuna etkilidir. Viral RNA polimerazı inhibe ederek viral replikasyonu durdurur. ${ }^{[2]}$ Favipiravirin hangi amaçla kullanıldığına bağlı olarak farklı dozlanması söz konusudur. COVID-19 tedavisi için yüksek dozlar seçilmelidir. Genellikle iyi tolere edilen ve yan etkileri ılımlı olan bir ilaçtır.En sık gözlenen yan etkiler: diyare, serum transaminaz (ALT, AST, ALP) artış ve nötrofil düzeyinde azalmadır. Sindirim sistemi yan etkileri (bulantı, kusma) görülebilir. ${ }^{[3]}$

Lopinavir/ritonavir: LPV/RTV HIV-1 tedavisi için kullanılan bir proteaz inhibitörüdür. Lopinavir sabit dozda farmakokinetik güçlendirici olarak ritonavirle kombine edilmiştir. Lopinavir, SARSCoV- 2'nin ana proteazını inhibe ederek viral replikasyonu durdurur. ${ }^{[4,5]}$ Infectious Diseases Society of America (IDSA) kılavuzu; LPV/RTV 'in sadece klinik çalışma amaçlı kullanılmasını, COVID-19'lu hastaların tedavisinde LPV/RTV ve diğer HIV-1 proteaz inhibitörlerinin tedavideki yerini belirlemek için klinik çalışmalara intiyaç olduğunu belirtilmiştir. Sağlık bakanlığının 11 Mart 2020 COVID-19 tedavi rehberinde; LPV/RTV ( 2 x 400/100, 10-14 gün) COVID- 19 ağır hastalık tablosunda kullanılması önerilmekteydi. ${ }^{[6]}$ Mevcut veriler, şimdilik LPV/RTV COVID-19 tedavisindeki rolünün sınırlı olduğunu düşündürmektedir. Kullanıldığı durumlarda; LPV/RTV kombinasyonunun ciddi ilaç etkileşimleri olduğunu unutmamak gerekir En sık gastrointestinal ve hepatotoksik yan etkiler görülmektedir. ${ }^{[7]}$

Bu çalışmada, üçüncü basamak bir hastanede FPV ve LPV/RTV ile tedavi edilen COVID-19 tanısı almış hastalarda tedavinin klinik etkinliğinin ve ilaç yan etkilerinin değerlendirmesi amaçlandı.

\section{GEREÇ VE YÖNTEM}

Çalışmaya üçüncü basamak bir hastanede, enfeksiyon hastalıkları servisinde 15.03.2020-30.04.2020 tarihleri arasında
COVID-19 tanısı ile yatırılarak takip edilen 46 hasta dahil edildi. Çalışmaya hastanemiz Tıpta Uzmanlık Eğitimi Kurulu (TUEK) tarafından 08.05.2020 tarihli 38-10 karar no ile onay alınmıştır. Hastalar 18 yaş ve üzeri idi. Ateş, öksürük, boğaz ağrısı, baş ağrısı, halsizlik, diyare gibi belirtiler ile başvuran hastalarda Real time Polimeraz zincir reaksiyonu (RT-PCR) ile konfirme edilen COVID-19 tanısı alan hastalar çalışmaya dahil edildi. RT-PCR negatif olan hastalar çalışma dışı bırakıldı. COVID-19 pozitifliği RT-PCR yöntemi ile viral nükleik asit varlığı gösterilerek tanımlandı. Hastaların tümüne yatış öncesi toraks tomografisi çekildi. Çalışma FPV kullanan 34 hasta ve LPV/ RTV kullanan 12 hasta olmak üzere iki grupta incelendi. FPV, COVID-19 vakalarının tedavisinde birinci gün $2 \times 1600 \mathrm{mg} / \mathrm{gün}$, sonraki günler $2 \times 600 \mathrm{mg} / \mathrm{gün}$ olarak toplam 5 gün verildi. LPV/RTV (2x400/100) 14 gün verildi. Hastalar tedavi sonrası 14 gün takip edildi. Bu iki grupta pnömonisi olan hastalar 3 grupta sınıflandırıldı:

1-Komplike olmamış (Ateş, kas/eklem ağrıları, öksürük, boğaz ağrısı ve nazal konjesyon gibi bulguları olup solunum sıkıntısı, takipne ve $\mathrm{SpO} 2<\% 90$ olmayan)

2-Hafif seyirli pnömonisi olan (Ateş, kas/eklem ağrıları, öksürük, boğaz ağrısı ve nazal konjesyon gibi bulguları olup, solunum sayısı <30/dakika olan, oda havasında $\mathrm{SpO}_{2}$ düzeyi $\% 90$ 'ın üzerinde olan, akciğer grafisinde veya tomografisinde hafif pnömoni bulgusu olan hasta)

3-Ağır pnömonisi olan olgularda (Takipnesi olup ( $\geq 30 /$ dakika), oda havasında $\mathrm{SpO} 2$ düzeyi $\% 90$ 'ın altında olan, akciğer grafisinde veya tomografisinde bilateral yaygın pnömoni bulgusu saptanan hasta). ${ }^{[8]}$

\section{İstatistiksel analiz}

Veriler bilgisayar ortamında SPSS 18.0 programında değerlendirildi. Tanımlayıı istatistik analizinde kategorik verilerde yüzde dağılımlar, sayısal sürekli verilerde ortalama standart sapma min-max kullanıldı. Grupları karşılaştırmada ki-kare ve $t$ testi kullanıldı. $P<0.05$ istatistiksel olarak anlamlı kabul edildi.

\section{BULGULAR}

COVID-19 tanısı alan 46 olgu çalışmaya alınmıştır. Hastaların $29^{\prime}$ u (\%63) erkek, 17'si (\%37) kadındı. Toplam 46 hasta 2 grupta değerlendirildi. Birinci grupta FPV kullanan 34 hasta, ikinci grupta LPV/RTV kullanan 12 hasta mevcuttu. Yaş ortalaması $57,80 \pm 17,78$ (yaş aralığı 18-91). Birinci grubun yaş ortalaması $57,71 \pm 17,33$, ikinci grubun yaş $58,08 \pm 18,81$ idi. Çalışmaya dahil edilen COVID-19 olgularının özellikleri Tablo 1 'de gösterildi. İki kolun özellikleri arasında önemli bir fark yoktu.

Hastaların tümünde ateş en sık başvuru semptomu idi (\% 69.6). FPV kolunda sırasıyla ateş (\%68.8), halsizlik (\%77.8), öksürük $\% 69.2$ en sık başvuru semptomları idi. LPV/RTV kolunda sırasıyla ateş (\%31.2), öksürük (\%30.8), boğaz ağrısı (\%28.6) en sık başvuru semptomları idi. FPV kolunda ateşi olan hastaların tedavi ile ortalama normale dönüş süresi $3,56 \pm 1$ gün idi. LPV/ RTV kolunda ateşi olan 10 hastada ateşin normale dönme 
süresi 4,42 \pm 1 gün idi. FPV kolunda kontrol RT-PCR tedavinin 5. güne tamamlanmasının ardından 6. gün alındı. LPV/RTV kolunda RT-PCR tedavi 14 güne tamamlandıktan sonra alındı. FPV kolunda; altıncı günde 34 hastanın 16'sında (\%47) RTPCR negatifleşti, altıncı gün bakılan RT-PCR sonuçları pozitif çıkan 18 hastanın bir hafta sonra bakılan RT-PCR'ının 16'sının negatif çıktığı, kalan 2 hastanın bir hafta sonra bakılan RT-PCR sonuçların negatifleştiği görüldü.

LPV/RTV kolunda; on beşinci günde bakılan RT-PCR sonucunda toplam 12 hastanın 10'u $(\% 83,3)$ negatifleşti, kalan 2 hastanın bir hafta sonra bakılan RT-PCR sonuçların negatifleştiği görüldü. FPV kolunda komplike olmamış pnömoni olgusu yoktu. Toplam hastaların \%50'si ağır pnömoni idi.

FPV ve LPV/RTV kullanımına bağlı yan etkiler Tablo 2'de gösterilmiştir

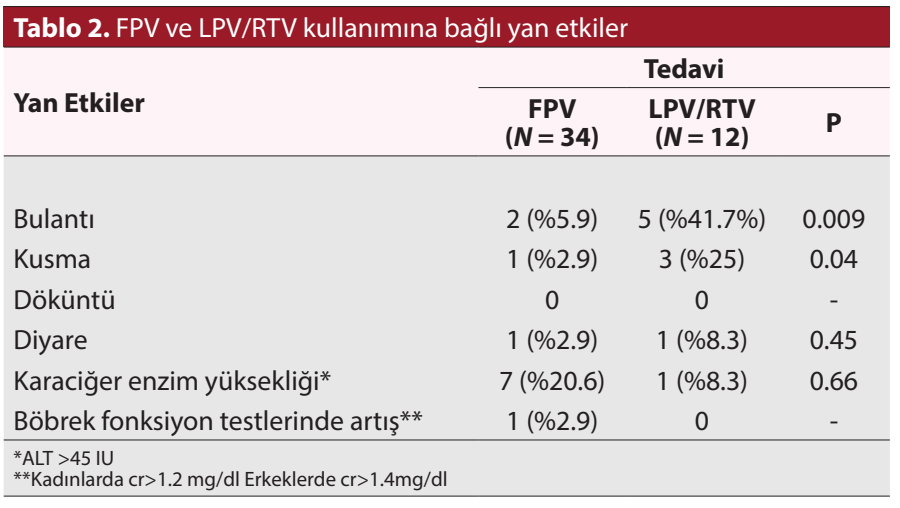

FPV kolunda 12 (\%35.2) yan etki görülürken LPV/RTV kolunda 10 (\%83.3) yan etki gözlendi. Karaciğer enzim yüksekliği FPV kolunda belirgin yüksekti (\%20.6). Bulantı-kusma ise LPV/RTV kolunda yüksek (sırasıyla 41.7\%, 25\%) görüldü. Bu yükseklik istatistiksel olarak anlamlı idi (p değeri sırasıyla; 0,009, 0,04). İlaç kesilmesini gerektiren ciddi bir yan etki gelişmedi. LPV/ RTV kolunda tedavi sonrası 2 hasta (\%1.6) hayatını kaybetti. FPV kolunda ise 4 hasta (\%1.1) hayatını kaybetti. Toplam LPV/ RTV ve FPV kullanan hastalara (n:46) bakıldığında mortalite $\% 1.6$ olarak saptandı.

\section{TARTIŞMA}

COVID-19 hastalığının şu ana kadar etkinliği kanıtlanmış, güvenilir çalışma sonuçları ile gösterilmiş bir tedavisi bulunmamaktadır. Destekleyici bakım, COVID-19 tedavisinin halen temelini oluşturmaya devam etmektedir. Şu anda, çeşitli antiviral ve immünomodülatör ajanlar, COVID-19 tedavisinde değerlendirme aşamalarındadır. LPV/RTV ve FPV tüm dünyada sıklıkla kullanılan ajanlar arasında bulunmaktadır. ${ }^{[9]}$ Yapılan çalışmalar ile COVID-19 için kullanılması önerilen ilaçların etkinliği ve yan etkileri tedaviye ışık tutacaktır. Laboratuvarda doğrulanmış COVID-19 tanısı alan 80 hastanın incelendiği bir çalışmada FPV ile tedavi edilen 35 hasta, LPV / RTV ile tedavi edilen 45 hasta incelenmiştir. FPV ile tedavi edilen hastalar için ortalama viral klerens süresinin 4 gün olduğu LPV / RTV ile tedavi edilen hasta grubunda 11 gün olduğu saptanmıştır. FPV kolunda viral klerensin anlamlı derecede daha kısa olduğu görülmüş. FPV grubundaki iki hasta da, 18. ve 21. Günlerde

Tablo 1. COVID-19 Olgularının Özellikleri

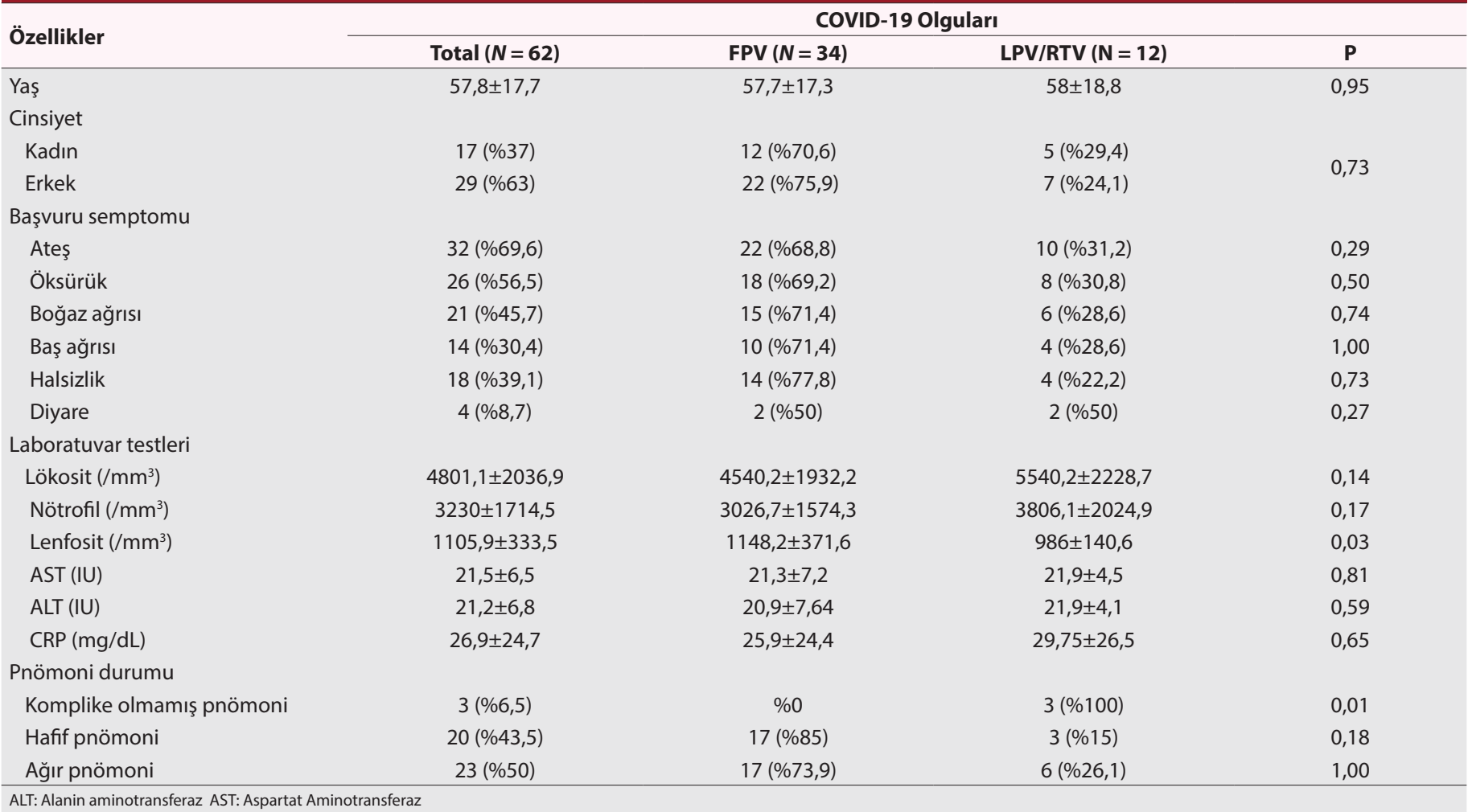


nazofaringeal sürüntüler de viral RNA'nın negatife döndüğü saptanmıştır. LPV / RTV grubundaki hastalar için, viral RNA saptaması 27 gün içinde negatif olmuştur. ${ }^{[10]}$ Çalışmamızda; RT-PCR, FPV kolunda tedavi tamamlandıktan sonra 6. günde, LPV/RTV kolunda tedavi 14 güne tamamlandıktan sonra alındı. FPV kolunda; altıncı günde 34 hastanın 16'sında (\%47) RT-PCR negatifleşmişti. Altıncı gün bakılan RT-PCR sonuçları pozitif çıkan 18 hasta bir hafta sonra tekrar kontrole çağrıldı ve RT-PCR yapıldı, 16'sının negatif çıktığı görüldü. Kalan 2 hasta bir hafta sonra kontrole çağrıldı ve RT-PCR yapıldı, sonuçların negatifleştiği görüldü. LPV/RTV kolunda; on beşinci günde bakılan RT-PCR sonucunda toplam 12 hastanın 10'u (\%83,3) negatifleşmişti. Kalan 2 hastada bir hafta sonra kontrol RT-PCR bakıldığında 2 hastanın da RT-PCR sonucu negatif geldi. Aynı çalışmanın FPV kolundaki toplam yan etki sayısı 4 (\%11.43) olarak saptanırken, LPV/RTV kolunda 25 yan etki $(\% 55,56)$ saptanmıştır ve yan etki görülme oranının LPV/RTV kolunda önemli ölçüde yüksek olduğu görülmüştür $(p<0.001)$. FPV kolunda görülen yan etkiler; iki hastada ishal, birinde karaciğer hasarı ve birinde iştahsızlık görülmüştür. LPV/RTV kolunda beş hastada ishal, beş hastada kusma, altı hastada bulantı, dört hastada döküntü, üç hastada karaciğer hasarı ve iki hastada göğüs ağrısı saptanmıştıı. ${ }^{[10]}$ Çalışmamızda benzer şekilde LPV/RTV kolunda yan etkiler oldukça yüksekti. LPV/ RTV kolunda $10(\% 83,3)$ yan etki görülürken FPV kolunda $12(\% 35,2) y a n$ etki gözlendi. Karaciğer enzim yüksekliği FPV kolunda belirgin yüksekti $(\% 20,6)$. Bulantı-kusma ise LPV/RTV kolunda yüksek (sırasıyla 41,7\%, 25\%) görüldü. Bu yükseklik istatistiksel olarak anlamlı idi ( $p$ değeri sırasıyla 0,009, 0,04). İlaç kesilmesini gerektiren ciddi bir yan etki gelişmedi. Yan etkilerin değerlendirildiği bir başka çalışmada FPV'nin yan etkileri arasında hafif ila orta şiddette diyare, kan ürik asit ve transaminazlarda asemptomatik artış ve nötrofil sayısında azalma saptanmıştır. ${ }^{[1]}$ LPV/RTV tedavisinin irdelendiği bir başka çalışmada gastrointestinal yan etkiler en yaygın görülen yan etkiler olarak saptanmış ve yan etkiler nedeniyle 13 hastada (\% 13.8) tedavi kesilmesi gerekmiştir. ${ }^{[12]}$ Çalışmamızda da FPV tedavisi alan hastalarda transaminaz yüksekliği sık görülen yan etkilerdendir ve diyare bir hastamızda görülmüştü, LPV/ RTV tedavisi alan hastalarda benzer şekilde gastrointestinal yan etkiler oldukça yaygındı fakat bizim çalışmamızda ciddi yan etki nedeni ile ilaç kesilmesini gerektiren bir durum oluşmadı. Mortalite oranları ülkelere göre oldukça değişkenlik göstermektedir. Çinde yapılan birkaç çalışmada genel mortalite oranları\%3,6, \%2,5\%3,8 olarak saptanmıştır. ${ }^{[13-15]}$ Sadece tedavi alan hastaların değerlendirildiği çalışmamızda mortalite oranı oldukça düşüktü $(\% 1,6)$. Çalışmamızda LPV/RTV kullanan hasta sayısı az olduğundan çıkan sonuçların değerlendirmesinde birkaç alternatif yorum yapılabilir. Illk olarak, LPV/RTV ile tedavi edilen grupta sayı oldukça az olmasına rağmen yan etki nerdeyse tüm hastalarda görülmüştür. Bu sonuçlar hasta sayısı az olsa da değerlidir. Íkinci olarak LPV/RTV kolunda viral RNA'nın saptanmama oranın yüksek olması ve bu dramatik iyileşmenin; tedavinin önerildiği üzere FPV kolunda tedavi süresinin beş gün, LPV/RTV kolunda ise 14 güne tamamlanarak daha uzun verilmesinden ve virüsün doğası gereği kendini sınılamasından kaynaklanabileceğini akılda bulundurmak gerekir. Dolayısıyla bu durum ilaç etkinliğini değerlendirmede yanıltıcı sonuçlar oluşturabileceğini düşündürmektedir. LPV/RTV ve FPV tedavisinin COVID-19 tedavisi üzerindeki doğrudan etkisini anlamak için daha fazla veri toplanması gerekmektedir.

\section{SONUÇ}

SARS-CoV-2 enfeksiyonu için henüz bilinen, etkinliği güvenilir çalışma sonuçları ile gösterilmiş bir tedavi bulunmamaktadır belirli ilaçlar henüz şimdilik birleştirilmemiş̧ir. Hedefimiz, eldeki verilerle etkili tedavileri tanımlamak için sonuçları paylaşmaktı. LPV/RTV tedavisi ile viral kilerens oldukça yüksek iken yan etki neredeyse tüm hastalarda görülmüştür. FVP kullanan hastalarda viral kilerens LPV/RTV koluna göre daha az olmakla beraber ilaca bağlı gelişen yan etkilerde daha azdı. Sonuçlarımız SARS-CoV-2 enfeksiyonunun tedavisi için ön veri sağlamıştır. Ayrıca, antiviral tedavi denemeleri için birincil son nokta olarak kullanılabilen ve COVID-19 ile ilgili tedavileri araştıran protokollerin tasarlanması için faydalı bir sonuç olabilecek viral klirens zamanını ve yan etki spektrumunu göstermeye çalıştık COVID-19 tedavisinde etkinliği tam olarak bilinmeyen bu ilaçların yarar sağlayacağı umut edilmektedir.

\section{ETIK BEYANLAR}

Etik Kurul Onayı: Çalışmaya hastanemiz Tıpta Uzmanlık Eğitimi Kurulu (TUEK) tarafından 08.05.2020 tarihli 38-10 karar no ile onay alınmıştır.

Aydınlatılmış Onam: Bu çalışmaya katılan hasta(lar)dan yazılı onam alınmıştır.

Hakem Değerlendirme Süreci: Harici çift kör hakem değerlendirmesi.

Çıkar Çatışması Durumu: Yazarlar bu çalışmada herhangi bir çıkara dayalı ilişki olmadığını beyan etmiş̧lerdir.

Finansal Destek: Yazarlar bu çalışmada finansal destek almadıklarını beyan etmişlerdir.

Yazar Katkıları: Yazarların tümü; makalenin tasarımına, yürütülmesine, analizine katıldığını ve son sürümünü onayladıklarını beyan etmişlerdir.

\section{REFERENCES}

1. Sanders JM., JM, Monogue ML, Jodlowski TZ, Cutrell JB. Pharmacologic Treatments for Coronavirus Disease 2019 (COVID-19) A Review. JAMA. 2020; 323(18): 1824-36.

2. Mentre F, Taburet AM, Guedj J, Anglaret X, Keita S, Lamballeria de X, Malvy $D$ et al. Doseregimen of favipiravir for Ebola virüs disease. Lancet Infect Dis, 2015 15(2):150-51.

3. Shiraki K, Daikoku T. Favipiravir, an anti-influenza drug against lifethreatening RNA virüs infections Pharmacology\&Therapeutics. 2020; 209.

4. Choy KT, Yin-Lam Wong A, Kaewpreedee P, Fun Sia S, Chen D, Pui Yan Hui $\mathrm{K}$ et al. Remdesivir, lopinavir, emetine, and homoharringtonine inhibit SARS-CoV-2 replication in vitro. Antiviral Research, 2020; 178. 
5. Sanders JM, Monogue ML, Jodlowski TZ, Cutrell JB. Pharmacologic Treatments for Coronavirus Disease-2019 (COVID-19). JAMA. 2020 (323)18: 1824-36.

6. Bilim Kurulu Çalışması. COVID-19 (SARS-CoV-2 enfeksiyonu) Rehberi. TC. Sağlık Bakanlığı Halk Sağlığı Genel Müdürlüğü 11 Mart 2020 Ankara

7. Furuta $Y$, Gowen BB, Takahashi K, Shiraki K, Smee DF, Barnard DL. Favipiravir (T-705), a novel viral RNA polymerase inhibitor. Antiviral Res. 2013;100(2):446-54.

8. T.C.SağlıkBakanlığıHalkSağlığıGenelMüdürlüğüCOVID-19Rehberi.https:// hsgm.saglik.gov.tr/depo/birimler/Bulasicihastaliklardb/hastaliklar /2019_n_CoV/rehberler/COVID-19_RehberiV5-5Subat2020.pdf (Erişim tarihi: 13 Nisan 2020).

9. Simsek Yavuz S, Unal S. Antiviral treatment of COVID-19. Turk J Med Sci. 2020;50(SI-1):611-19.

10. Cai Q, Yang M, Liu D, Chen J, Shu D, Xia J et al. Experimental treatment with favipiravir for COVID19: an open-label control study. Engineering. 2020. In press.

11. Madelain V, Nguyen Tram TH, Olivo A, Lamballerie de X, Guedj J, Taburet $\mathrm{AM}$ et al . Ebola virusinfection: review of the pharmacokinetic and pharmacodynamic properties of drugs considered fortesting in human efficacy trials. Clin. Pharmacokinet. 2016;55: 907- 23.

12. Cao B, Wang Y, Wen D, Liu W, Wang J, Fan G et al. A Trial of LopinavirRitonavir in Adults Hospitalized with Severe Covid-19. N Engl j Med. 2020; 382(19): 1787-99.

13. Zhou F, Yu T, Du R, Fan G, Liu Y, Liu Z et al. Clinicalcourseand risk factors for mortality of adult in patients with COVID-19 in Wuhan, China: a retrospective cohort study. The Lancet 2020; 395:1054-62.

14. Ji Y, Ma Z, Peppelenbosch MP, Pan Q. Potential association between COVID-19 mortality and health-care resource availability. The Lancet. 2020;8: 480.

15. Li X, Xu S, Yu M, Wang K, Tao Y, Zhou Y et al. Risk factors for severity and mortality in adult COVID-19 inpatients in Wuhan. J Allergy Clin Immunol. 2020; 146(1): 110-18. 